\title{
RUSSIA'S FOREIGN POLICY TOWARDS CRIMEAN SEPARATISM: ITS LEARNING FROM THE GEORGIA-RUSSO WAR
}

\author{
Lunyka Adelina Pertiwi ${ }^{a}$ and Wan Sharina Ramlah Wan A.A. Jaffri ${ }^{b}$
}

\begin{abstract}
This paper discusses how Russia's foreign policy towards Crimea is influenced by its policy towards separatism in Georgia. By applying the concept of political learning, this paper aims to analyse how Russia's learnings on its policy to militarily support Abkhazian and South Ossetian separatists in the Georgia-Russo War has underpinned its policy to support Crimean separatists more peacefully. Based on library research, this paper explains Russia's external and internal environment during the Crimean crisis; observation on the Georgia-Russo War; changes in belief supported by critical perception on those two environments; transformed policy and its effectiveness. This paper finds that Russia's observation on its operational failures in the Georgia-Russo War, and belief change into the importance of more accurate tactics and minimum casualties in order to also adapt towards NATO and European Union enlargement and resurgence of domestic dissidents had influenced the policy to use ambiguous warfare in Crimea. This political learning effectively strengthens Russia's regional primacy and domestic nationalism.
\end{abstract}

Keywords: Russia, separatists, political learning, failures, belief change, external and internal environments

\section{INTRODUCTION}

Russia's foreign policy has always tried to preserve its characteristics as the strongest nation, which inherits the high profile of Soviet Union, with big aspirations, to remain dominant across the near abroad ${ }^{i}$ and to revive 'Greater Russia' (Nygren, 2008, p. 8). Russia started to achieve these under Boris Yeltsin's leadership, which admitted values and sovereignties of former Soviet Union republics, as well as embracing them under the system of the Commonwealth Independent States (CIS).

The CIS was founded on 8 December 1991 when three states, namely Russia, Ukraine and Belarus signed the Creation Agreement, whereby membership was open to all states of the former Soviet Union. Azerbaijan, Armenia, Kazakhstan, Kyrgyzstan, Moldova, Tajikistan, Turkmenistan and Uzbekistan joined the CIS on 21 December 1991, with Georgia becoming the latest state to join in December 1993. Through bilateral political, economic and military cooperation, and settling conflicts on behalf of the CIS, Russia was able to boost diplomatic relations and be responsible for retaining the historical-cultural and high profile aspects of Soviet Union, with Russia being frequently involved as mediator for bilateral disputes between CIS members and separatist-related conflicts.

a Corresponding Author: Lunyka A. Pertiwi (lunyka.pertiwi@gmail.com) is a Research Assistant at the University of Sydney. Email: lunyka.pertiwi@gmail.com

b Wan Sharina Ramlah Wan A. A Jafri is a Lecturer at the Department of International and Strategic Studies, University of Malaya, Malaysia. Email: wanshana@um.edu.my 
Russia faced the most complicated confrontations with two CIS members namely Georgia and Ukraine, in 2008 and 2014 respectively, arising from separatist movements in both countries. Russia's choice to support Abkhazian and South Ossetian separatists through a military war against Georgia had led to speculations by most international analysts and media outlets that Russia would target Crimea as an arena of future conflict. The logical reason underlying this speculation was that Crimea was mostly inhabited by Russians who were anti-Western, although this territory was under Ukrainian authority (Hadenskog, 2008, p. 7). Six years later, Crimea was in fact, annexed by Russia.

Delcour and Wolczuk (2015, pp. 464-472) state that both Georgia and Ukraine preferred democratic values by forging closer diplomatic ties with the West, and the Georgia-Russo War and the annexation of Crimea were Russia's efforts to destabilize and undermine both countries' territorial integrity and statehood to slow down their democratization process. According to Tara Kuzio (2016), Ukraine had predicted and been wary of Russia's manoeuvres to annex Crimea, although Crimean separatists were categorised as a frozen contrariness for Ukraine. Kiev understood well how Georgia had become tumultuous in fighting against Russia's intervention.

On the other hand, Kuzio also states that Kiev had failed to fend off the annexation of Crimea because Kiev had no robust Western support. The West had been proven to be weak in imposing sanctions against Russia's policy using little green men and local ethnic entity in Crimea. Furthermore, regardless of Russia's foreign policy instruments, Russia had moral justifications to support its unilateral intervention. In Georgia for example, besides reason of protection for its citizens and ethnicities who lived inside and outside Russia's borders, Russia upheld one word, i.e. 'humanity' to defend its additional military personnel deployment in Abkhazia and South Ossetia. These similar excuses were availed in Crimea and had enhanced Russia's confidence to reject the West's allegations that Russia illegally annexed Crimea, and to define its action as accession.

However, these literatures only highlighted Russia's encouraging reasons for its foreign policy towards Crimean separatists in Ukraine which were compared with Russia's policy towards Abkhazia and South Ossetia separatists in Georgia, and ignored that Russia's policy on Crimea was influenced by its policy towards separatists in Georgia. Based on the background of problem mentioned above, this paper will discuss how Russia's lessons from its policy to militarily support Abkhazian and South Ossetian separatists in the Georgia-Russo War in 2008 had underpinned its relatively peaceful policy to support Crimean separatists in 2014. It is expected to fill the gap of knowledge left by the existing literatures.

For the purpose of examination, this paper is divided into five parts and uses library research on scholarly articles and documentary sources. This paper begins with the basic conceptualisation of Jack Levy's foreign policy learning which emphasizes on political learning. In the second section, this paper describes Crimean separatistsrelated issues involving the history of this movement briefly; exploration on Russia's external and internal environments - namely NATO and the European Union (EU) enlargement and domestic dissidents, coinciding with Crimean separatist issues. The third section scrutinizes Russia's political learning process, consisting of the 
observation on operational failures in the Georgia-Russo war, the belief change involving critical perception on external and international environments, and Russia's transformed policy into the implementation of ambiguous warfare towards Crimean separatist issues. The effectiveness of Russia's political learning is explained in the fourth section, and this paper closes with a conclusion consisting the main findings for answering the research questions which include -

- Russia's assessment on its previous failures and belief change with regard to minimum bloodshed and more tactical operations to address Crimean separatists;

- Adaptation with external and internal environments underpinned the policy to use ambiguous warfare tactics, namely little green men and a designated Russian ethnic entity.

This learning was effective and judged to have successfully enhanced Russia's primacy at national and regional levels.

\section{CONCEPTUALIZING FOREIGN POLICY LEARNING}

Foreign policy, according to Kenneth Waltz, emerges from political institutions and decision makers with their certain characters propped by experience, tradition and pressure. In relation to that, there is a process of understanding of prior events or experiences called learning. For more complex definition, Levy (1994) suggests that foreign policy learning is a change of beliefs (or degrees of confidence on one's beliefs) or a development of new beliefs, skills, or procedures as a result of observation and interpretation of historical experiences.

Reiter simply states that foreign policy learning takes place at the level of state actors (Goldsmith, 2005, p. 25), and is not a passive activity. Actors should be actively absorbing and analysing lessons from foregoing events. They are then required to collect information supporting their valid interpretation of their experiences, and to promote ideas related to how they may perceive and be perceived by external adversaries and/or rivals.

Levy himself emphasizes on political learning to examine state's foreign policy learning. Political learning is more than the aggregation of individual new knowledge enhancement. It should also be able to recognize conflicts and values involved, so decision makers can modify goals or means for addressing foreign policy issues. Specific foreign issues faced by states can coincide with external and internal environments, which are identical with those in the past. Synder, Bruck and Sapin (2002) define external and internal environments, as follows -

\section{External Environment}

External environment (international community), among others, are types of actors, interactions, and arena scholars can observe.

Firstly, a direct central actor is a (non) state actor who is able to carry out a variety of decisions. This actor applies instrument(s) to targeted actors. Otherwise, there is a periphery actor who is at a lower level than a central actor, who transfers 
certain resources to a central actor. Policies of such actors will create patterns of interactions such as conflicts, alliances, war, arms race, competition, cooperation, economic sanctions and embargoes.

Secondly, scholars can determine an arena (Lentner, 1974, pp. 70-73) - the place where actors directly apply their instruments. It may be global, regional or local scopes of other countries.

\section{Internal Environment}

Internal environment (domestic conditions) refers to firstly, national political conditions and/or coalitions, or secondly, ideology or beliefs of major political elites and society in matters of their understanding and handling measures of issues (Aggarwal, 1998, pp. 12-13).

Political learning performed by a state actor involves two stages:

(1) observation and/or interpretation of experiences, leading to

(2) belief change which influences state's behaviours and alterations of solutions or objectives.

Incorporating critical perception on external and internal environments also contributes to the understanding of needs on changes (Ziegler, 1993, p. 166). Furthermore, this change commonly results in transformed policy including tactical solutions, basic strategic assumption or objectives to deal with issues. Lastly, political learning is deemed effective when the new policy successfully achieves the goals.

To ease an initial understanding as to how this paper applies a conceptualisation of political learning in relation to Russia's foreign policy towards Crimean separatists, a schematic diagram is presented in Picture 1.1.

Picture 1.1 Schematic of Russia's Political Learning

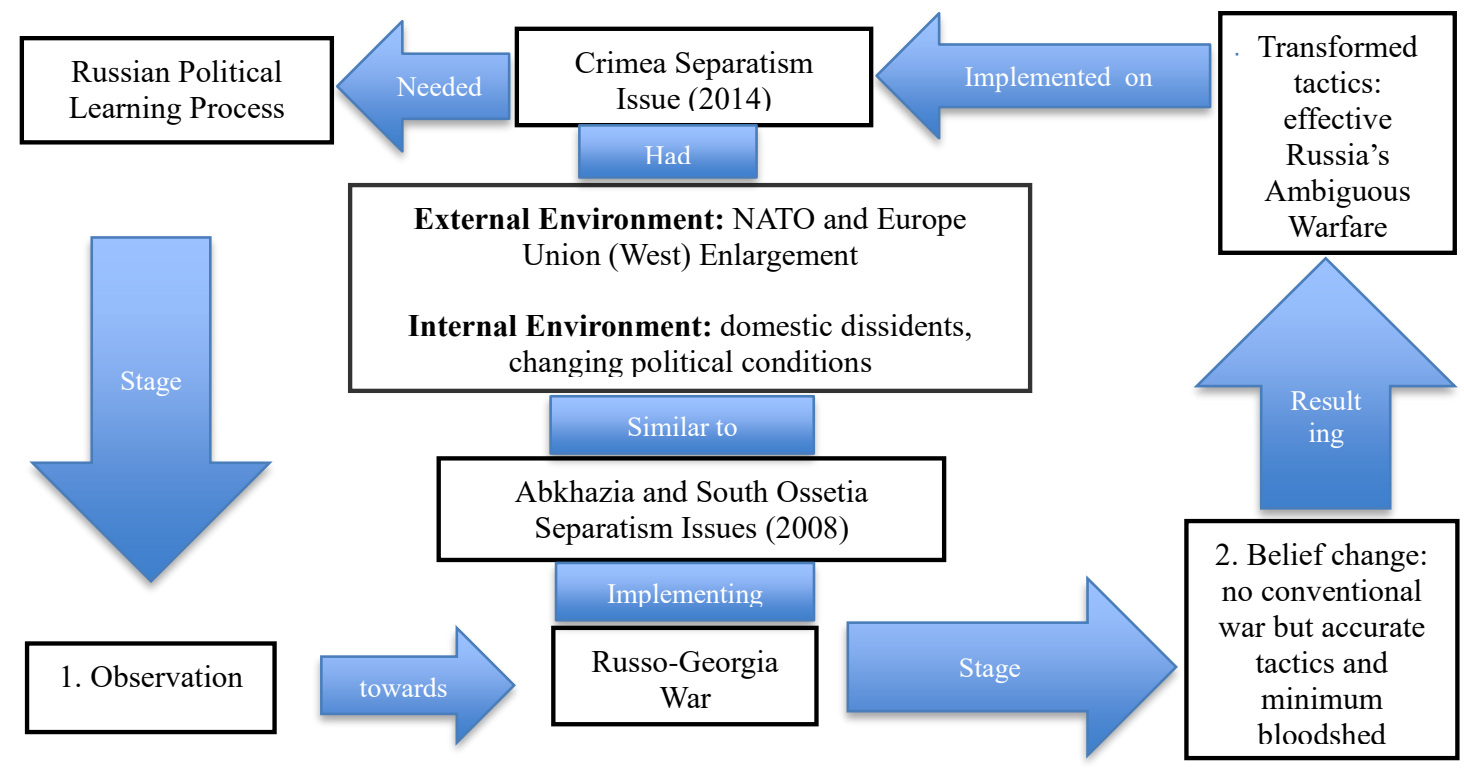




\section{CRIMEA SEPARATISM}

\section{History in brief}

In 1954, Soviet leader Nikita Khrushchev, in front of the Politburo of Soviet Communist Party Central Committee, decided to cede Crimea to Ukraine as compensation for all afflictions suffered, and for their struggle against Nazi Germany, in World War II. The spirit of separatism in Crimea, however, started to germinate as most of Crimea's population remained proud to be a part of the Soviet Union.

After the collapse of the Soviet Union in 1991, feuds between Crimea and Ukraine escalated although they did not appear to be anarchic, and nor were they engaged in military aggression, unlike the Abkhazian and South Ossetian separatists. In order to prevent further escalation, Kiev agreed to grant Crimea a right of greater autonomy through the Act on the Division of Powers Between the Authorities of Ukraine and the Republic of Crimea. However, the Crimean High Council still proclaimed that Crimea was an independent nation located inside Ukraine's territory.

In 2006, the Crimean Parliament issued a regulation that Crimea was a zone free of NATO forces as a response to the arrival of the United States Marine alongside the Ukrainian Marine at Feodosiya - one of the cities in Crimea. Three years later, an anti-Ukraine demonstration demanded Russia to provide maximum military support, just as the latter did to Abkhazian and South Ossetian separatist movements. These circumstances obviously stimulated tensions between Ukraine and Russia, with Moscow apparently trying to resolve the issue through peaceful diplomacy. Moscow's action seemed rather careful and cautious. Understandably, this was in order to ensure the continuity of a Moscow-Kiev agreement pertaining to matters of Russia's navy operational activities, and rights to build supporting facilities and infrastructures for its fleet in Sevastopol, a Crimean city and seaport.

However, domestic political turbulence returned to Ukraine in November 2013. It was ignited when a mass protest by pro-Western Ukrainians was held in Maidan Square in Kiev in an attempt to oust Ukrainian President Viktor Yanukovych (supposedly a Russia's proxy). As time went by, gathering points around Maidan Square transformed into battlefields for the protesters and Ukrainian Police. The government and opposition groups repeatedly negotiated to resolve this political friction, however, these always ended up in deadlocks. The continuous political chaos finally saw Yanukovych fleeing Ukraine on 22 February 2014, leading to Oleksander Turchynov from the opposition group becoming the Interim President while waiting for new elections to take place.

This unstable period of Kiev's political situation was seen as another chance by Crimea to permanently disassociate themselves from Ukraine. The Crimean High Council swiftly mandated Sergey Aksyonov, a Moldovan-born Crimean politician, to be the Crimean Prime Minister and arranged for a referendum for Crimea to join the Russian Federation. On Kiev's side, in anticipation of a wider demand for separation and the need to seize Russia's vital facilities and to contain Russia's influence in Crimea, a huge number of military personnel were deployed. In addition, permission for the use of the Russian language and the protection over Russian ethnic minority in 
Ukraine and Crimea were repealed (Chandler, 2014, Kofman, et.al, 2017, pp. 20-21). On March 5, 2014, the Crimean regional parliament responded to the above Ukraine's policies by accelerating a referendum scheduled from March 30, to March 16.

\section{NATO AND EU ENLARGEMENT AND DOMESTIC DISSIDENTS - COINCIDENCE WITH THE CRIMEAN CRISIS}

While Crimean separatist issues were drawing international attention, there were some issues in Russia's external and internal environments coinciding with it.

Firstly, in the scope of external environment, on 27 February 2014, Ukraine's First Deputy Minister of Defence Oleksandr Oliynyk held a NATO-Ukraine Commission (NUC) meeting to continue negotiation over the prospect of Ukraine's NATO membership, which used to be unclear during the Yanukovych regime. Therein, NATO Secretary General Anders Fogh Rasmussen implicitly emphasized its open-door policy -

"Today we made clear that NATO stands ready to support democratic development, defence reforms, military cooperation and democratic control over the security sector".

(NATO Website, 2014).

The United States, on behalf of NATO, committed to provide financial assistance packages of US\$1 billion and other emergency budget supports in order for Ukraine to restore its stability and sovereignty. Meanwhile, the EU had also loaned macro financial assistance as much as US\$4 billion and grants valued around US\$6.7 billion (Sofer, 2014, p. 6; Welt, 2017, pp. 11-17) to prevent Ukraine from spiralling into a monetary crisis, and to ease integration process with the EU.

Secondly, in the scope of internal environment, Alexyn Navalyn, a prominent dissident and Mayor of Moscow, had voiced out and celebrated the fall of Yanukovych's administration. He even revealed connection between Yanukovych's corrupted regime and Russia's political intervention in Ukraine during Yanukovych's term. Along with Navalyn, there was also Mikhail Khodorkovsky, the oil tycoon who regularly visited Kiev and Donetsk to hail unity of all Ukrainians.

Circumstances such as NATO's enlargement and criticisms from dissidents were also present before Russia made the decision to extend military support to Abkahazian and South Ossetian separatists who were fighting against Georgian armies. The slight difference was that the issue of the expansion of EU membership to Eastern European nations did not exist as Russia's external environment in 2008. Georgia was offered to open more intensive military cooperation and training with NATO during a NATO summit in Bucharest in 2008. At that time, it was perceived as a good signal for Georgia's EU membership request, which was made in 2003. Georgia believed that its official participation into NATO would be essential for Tbilisi's foreign policy in Europe.

Furthermore, in 2008 Russia was internally 'attacked' by the rise of Navalyn's blog revealing alleged malpractices and corruption at some of Russia's big state-controlled corporations. To gain information he became a minority shareholder 
in major oil companies, banks and ministries, and secretly inquired staffs about the shortcomings within Moscow's finances. His use of social media to deliver his message symbolised his political style reaching predominantly young followers (BBC, 2018).

\section{RUSSIA'S POLITICAL LEARNING}

The foregoing sections of this paper have described a brief milestone of Crimean separatism, as well as Russia's external and internal environments coinciding with this issue. This section will explain Russia's political learning process, which involved the following before implementing a transformed policy:

(i) Russia's observation on operational failures in its military back-ups in Abkhazia and South Ossetia, and

(ii) Russia's belief change propped by critical perception on NATO and EU's enlargement and domestic dissidents

\section{(i) Observation on Operational Failures in Abkhazia and South Ossetia}

Russia was required to have more effective policy towards Crimean separatists' demands. Its operational failures in the Georgia-Russo War must not be repeated in Crimea as these had given an indication to the West that Russia was not well-prepared in terms of their military assets.

According to the GRU - Glavnoe razvedyvatelnoe upravlenie (Main Intelligence Directorate) - many military seniors had criticised the overall quality of Russia's special armies' performances in the Georgia-Russo War. They suggested that their forces were unable to stave off Georgia's armies defences easily. Thus, what Russia can do in Crimea had to be more conceptualized (Gelotti, 2018). Putin understood these inputs and stated, "the army has 1.4 million men, yet there is no one to wage war" (Mazitans 2014, p. 5). In addition, his predecessor, Dmitri Medvedev had indicated that Russia's armies were not excellent. After the Georgia-Russo War ended, he had wanted to have a new look at Russia's military by calling for tremendous modernization and reformation immediately after a limited internal review. Such programmes needed to include upgrading of equipments and hightechnical military capabilities, particularly in order to be engaged in wars in the near abroad (Dugas 2016, pp. 6-7).

Russia's policy towards Abkhazian and South Ossetian separatists was designed to unequivocally maintain its periphery region and protect pro-Russian citizens and speakers outside its borders from pro-Western influences. The then President of Russia, Medvedev, ordered full military operations to aid Abkhazia and South Ossetia separatists to destroy economic and strategic facilities in Georgia's territories, and to tune pro-West Georgian government out of Abkhazia and South Ossetia. However, military senior officials and analysts observed that Kremlin had rushed into entering Abkhazia and South Ossetia with similar tactical weakness of war mindset which had led to Russia's poignant defeat in the Chechnya War I. They pointed that besides grappling with malfunctioned outdated military equipments, Russia's armies were not able to effectively paralyse Georgian air defence when the 
latter shot down a Russian bomber aircraft mission, TU-22 (Dugas 2016, pp. 30-35). In addition, they assessed that there should not have been unnecessary casualties reportedly to be around 64 Russian soldiers and 164 civilians in South Ossetia (Reuters, 2009), and inaccurate bombing raids. They compared these with the Georgian side and concluded that these losses could have been minimized by more accurate movements.

Despite an overwhelming number of Russian soldiers fighting alongside Abkhazia and South Ossetian separatists against Georgia, the fact remained that they faced issues of lacking in coordination, commands and supply of intelligence information. Anatoliy Tsyganok, ex-General Staff of Russian Armed Forces even commented that Georgia had subdued Russia in matters of information-technical battle although Russia, at the last moment, was declared to have won the GeorgiaRusso War (Iasiello, 2017, p. 52). These circumstances arose because Kremlin did not propagate the readiest and most well-trained armies, and did not possess sufficient number of local collaborators in Abkhazia, South Ossetia and Tbilisi. More importantly, Russia's armies were observed to have insufficient topographic knowledge of the mountain contours of Abkhazia and South Ossetia. This had led to commanders experiencing hardships in changing their movements and formations in anticipation of Georgian forces' attacks on land zones.

Such operational failures in the Georgia-Russo War inscribed that Russia's military capabilities were not splendid enough to respond to outbreak of wars, nor to secure the near abroad region, nor defend its geopolitical interests in the future. Christopher Langton from the London-based International Institute for Strategic Studies stated that, "there is no way they could say from this operation that they are capable of carrying out operations against something as sophisticated as NATO forces." (Lowe, 2008).

\section{(ii) Belief Change: Added by Critical Perception of Accurate Tactics and Minimum Casualties}

Russia's observations over failures in the Georgia-Russo War in Abkhazia and South Ossetia had encouraged its belief change that it is not all about winning the war, but that it also requires a more accurate strategies resulting in minimum failures and casualties (Dugas, 2016, pp. 36-37). A process of belief change was also completed by critical perceptions on motives of NATO and EU enlargement, and the resurgence of domestic dissidents.

According to Timothy Thomas (2015, p. 453), based on the observation of the Georgia-Russo War, Russia's General Staff built a belief that Russia ought to combine Alexander Svechin's theory; "strategy decides issues associated with the employment of the AF and all the resources of a country for achieving ultimate war aims" and the doctrine of ex- Russia's Chairman of General Staff Valerii Gerasimov, "The role of non-military means of achieving political and strategic goals has grown, and, in many cases, they have exceeded the power of weapons in their effectiveness" (Geleotti 2015, p. 157).

The need for change was incorporated with Russia's perception that the United States and its allies had always disregarded Russia, deeming them as "Pluto 
(stranger)" in a "political solar system" (Kumar Pandey, 2010, pp. 20-62). Although NATO and EU membership offers were extended to ex-Soviet states (including Ukraine), they targeted to expand the Western values in these former Soviet republics; erode Russia's relations with them; and alienate Russia's military forces from strategic maritime zones across the near abroad region. Related to this geopoliticalsecurity competition, for pacification of Russia's interests, the Black Sea became the only strategic area that could function as an open gate and a buffer zone for Russia's interests after its Kaliningrad's leverage across the Baltic Sea came under big threats when most of the political and security policies of former Soviet Union republics across Russia's western borders were pro-Western. Examples would be Poland and the Czech Republic who had agreed to be deployment sites for additional NATO missiles.

In addition, Russia ought to avert Western countries from underestimating Russia's military forces again, and not leave any flaws that might erode their pride as well as their grasps on the near abroad region. Meanwhile, Russia deemed domestic dissidents like Navalyn and Lhodorkovsky as agents of the West who worked to instigate the public and reduce the trusts of Russians in their Government (Miller, 2014). Russia under Putin sought to keep distance from Western (capitalist) values and show off its country as a primary and self-sustained government (Mankoff, 2009, p. 24). Ultimately, Russia's more peaceful measures are expected to deal with prolonged Crimean separatists' demands as well as taking total control at regional and national levels.

\section{TRANSFORMED POLICY: THE AMBIGUOUS WARFARE}

The belief change about the importance of more tactical measures and minimum casualties was implemented into ambiguous warfare tactics through little green men deployment, and a designated Russian ethnic entity. Ambiguous warfare is defined as situations in which a state or non-state belligerent actor deploys troops and proxies in deceptive and confusing manners (Connell \& Evans 2016, p. 31). The policy to use ambiguous warfare in Crimea was a transformation from the total use of military measures in the Russo-Georgia War.

Russia funded and ordered little green men who, as per Putin, were only a self-defence group originating from Crimean local communities (Rotaru 2018, pp. 59). These little green men looked like Russians, but they had basic military skills. Their manoeuvres were only limited to occupy several Ukraine's public, military and governmental facilities and buildings. Notwithstanding, other opinions believed that these little green men might be assigned to divert Ukrainian armies' attention. For example, Cornell and Evans (2016, p. 36) suggest that Russia's secret military operation in Crimea worked because Russia's Spetsnaz (elite forces) were able to supply equipments into some of their Black Sea Fleet's bases whereby they made their radio silent and undetectable by NATO monitoring radars. They then disorganized Ukraine troops on the field by confounding their communication system. This tactic had led to Ukraine armies leaving some of their posts in key infrastructures and lines across the peninsula. These circumstances finally gave Russia's naval squads free space to seize infrastructures throughout the peninsula. Gillich (2015, p. 1195 ) adds that the little green men were responsible for tricking Ukraine, so that 
Russia's most well-trained and professional armies and modern military equipment could enter Crimea and be ready for a possible open war with Ukraine.

In addition, Russia had also allowed a designated Russian ethnic entity (russkii) in Crimea to carry out pro-Russia campaigns. It held massive protests across Crimea. For example, in February 2014, 10,000 pro-Russian groups had rallied and shouted the word "Russia" in front of Simferopol's regional parliament building. The most epic moment was when many of them replaced Ukraine's national flag on the top of the building with a Russian flag.

A designated ethnic Russian entity had been created by Russia since the end of Ukraine's Orange Revolution in 2005. It was composed of pro-Russia governmental officials, cultural or educational agents, media and journalists, who initially infiltrated to dispense Russian language and values through mass media and cultural and ideological enhancement and education in Crimea. Cadier and Light (2015, p. 64) suggest that a designated ethnic Russian entity was a good investment (as local collaborators), which then could be one of the key factors to simplify Russia's operation in Crimea in 2014. This entity served as an essential actor, rather than just a historical tie between Simferopol and Moscow due to its functions of, inter alia, fending off local resistance towards Russia, increasing Russians' nationalism in Crimea and supplying intelligence information to Russia.

\section{EFFECTIVE RUSSIA'S POLITICAL LEARNING: SUCCESS OF POLICY TOWARDS CRIMEAN SEPARATISM}

Effective Russia's political learning of the Georgia-Russo War had resulted in transformed policy from the use of military measures into ambiguous warfare of which its implementation had not only assisted Crimean separatists, but also symbolized Russia as a balancer against Western hegemony, security provider for the near abroad and clever powerful leaders in front of its citizens. In fact, Russia's policy to carry out ambiguous warfare was too sophisticated and well orchestrated for the West to properly react on (Balasevicius, 2017, p. 26). Such policy did not cause a huge number of casualties while Russia was gaining full control of Crimea, thus NATO and the EU could not counter it by means of conventional military forces.

On the other hand, even if the Western nations took into account of diplomatic solutions, they remained stuck on the difficulties in seeking to comprehend details of Russia's ambiguous tactics. These circumstances automatically gave Russia ample time to readily prepare logical pretexts to counter any possible Western allegations. The United Kingdom Defence Committee had even criticised NATO and the EU for not being well prepared to respond to Russia's tactical operations in Crimea within the critical weeks prior to the annexation (Balasevicius, 2017, p 26; Barber, 2017, pp. 46-52). This was different from the response of the Western nations during the Georgia-Russo War. Seeing how the Georgian armies struggled to defend themselves from the separatists' and Russia's military onslaught, on top of NATO's auxiliary military equipment, Nicholas Sarkozy, on behalf of the EU, had met Dimitri Medvedev for a truce plan on 12 August 2008. This was followed by further negotiations. Although there were no permanent mutual agreements on the remaining series of negotiations, at least the West had clearly made diplomatic efforts.

Basically, all the efforts carried out by the little green men and those designated Russian ethnic entities had successfully contributed to the elimination of 
Western and Ukrainian pressures on Crimea, thus allowing its officers to prepare for the planned referendum.

On 16 March 2014, a public referendum took place in Crimea. The counting of the votes was carried out promptly and speedily, and was trouble-free that it shocked the world, particularly the Western nations. An overwhelming 96.77 percent of voters had voted for Crimea's reunification with Russia. On 18 March 2014, the Crimean regional government and Russia's representative signed the document of integration. This was followed by the amendment to the Constitution by the Deputy Chairman of Russia's Parliament to the effect of recognizing this new territory to enter the Russian Federation several days later. On 27 March 2014, the United Nations issued Resolution No. 62/262 which recognized Ukraine's sovereignty and territorial integrity, and reaffirmed that Russia's annexation of Crimea was illegal. Notwithstanding, according to Burke-White (2014, pp. 1-7), Russia cleverly embraced international law while annexing Crimea. Russia did not deploy obvious special military forces or regular soldiers to Crimea, although some Western leaders and analysts challenged this publicly. It was very hard to prove that the little green men were in fact Russian Armed Forces and not self-defending local community mobilized by Russia. Russia persistently quibbled that the presence of the selfdefending group was to assure that Russian citizens and ethnics in Crimea were protected from possible abuse by Ukrainian armies, and not to initiate feuds.

As for to the referendum, a designated Russian ethnic entity had successfully ensured that Russian ethnics in Crimea were distinguishable from the Ukrainians. As a consequence, votes could be claimed to be transparent and free from Russia's pressures and fraud. It automatically fitted the international legal order of selfdetermination being the rights of all people. According to Friendly Relations Declarations, those seeking self-determination constitute distinct people who have been subject to a systemic oppression and have chosen their future in legitimate ways through democratic process (Talmon 2013, p. 236).

Lastly, this policy had enhanced nationalism and patriotism in domestic Russia. Polling from VTsIOM revealed more than 90 percent of Russians approved of Crimean comeback under Russia. Although the West neglected the said survey, this policy had made Russia under Putin administration gaining more support from domestic populist groups in the Spring of 2014, and distracted Russia's public from negative issues released by dissidents. (Allison 2014, pp. 1291-1292).

\section{CONCLUSION}

It has been shown that Russia's political learning involving observation of its operational failures in the Georgia-Russo War and a belief change into managing a war with more accurate tactics and minimum casualties in responding to Crimean separatists' demand to join the Russian Federation had led to success. Russia's adaptation to external and internal environments, namely NATO and the European Union enlargement and the resurgence of domestic dissidents had influenced Russia's policy to use ambiguous warfare in Crimea. This warfare which combined the deployment of little green men with designated Russian ethnic entity had worked. More importantly, this political learning had effectively strengthened Russia's public 
nationalism and regional primacy as a security giver for the near abroad, and a balancer vis-a-vis Western hegemony.

Crimean separatist movement emerged after Nikita Khrushchev ceded Crimea to Ukraine in 1954. An unstable political situation which engulfed Kiev from November 2013 to February 2014 was seen as an opportunity by Crimea to vow for referendum and disassociate itself from Ukraine permanently. During this critical period, NATO and the EU revealed the possibilities of Ukraine entering their blocs. In the national scope, Russia had to face the resurgence of domestic dissidents such as Alexyn Navalyn and Mikhail Khodorkovskyt. These conditions were identical to those faced by Russia before Russia adopted the policy to fight alongside Abkhazian and South Ossetian separatists against Georgia in 2008.

To respond to Crimean separatists' demand, Russia was required to undertake foreign policy learning by observing several fatal operational failures in the RussoGeorgia War. Although Russia claimed victory in Abkhazia and South Ossetia, its decision makers and military generals had assessed that Russia's armies lacked coordination, commands, and intelligence information supply on the battlefield. These were all caused by insufficient number of well-prepared and professional armies, and local collaborators. In addition, the generals also criticised the inability of Russian armies' in adapting and making rapid movements in Georgia's mountain contours, and attacking Georgia's air defence. These had led to Russia suffering morally from the loss of 64 soldiers and 164 civilians of South Ossetia.

This observation stage was followed by Russia's belief change. This belief change process incorporated critical perceptions of Russia's external and internal environments. Such perceptions contributed to the comprehension on the need for change. The belief change emphasized that a war with more accurate tactical operations and minimum casualties was necessary to deal with Crimean separatists' willingness. Furthermore, Russia perceived that NATO and EU membership offers to Ukraine had eroded Russia's military and political influence in the near abroad, especially when domestic dissidents who were said to be agents of the West were trying to generate Russian people' distrust of their government and values. Compounded to these, near abroad states along the Black Sea which Russia believed to be the most strategic post to balance Western political and military influences, were forming strategic ties with the West. With these understandings, Russia was determined to not let Western nations look down on Russia any more. Nothing but more peaceful measures in Crimea was expected to likely enhance the pride of Russians, as well as its holds on the near abroad.

The belief change was implemented into a policy to use ambiguous warfare tactics, namely the deployment of little green men and a designated Russian ethnic entity to Crimea. Such warfare was a transformation from the use of total military measures. Russia claimed that the little green men were local Crimeans who had basic military skills. A designated Russian ethnic entity served as local collaborators in Crimea for the Russian Government.

This learning process was believed to be highly effective. Many Western analysts suggest that the complexity of the ambiguous warfare policy had made the Western nations baffled as to how they should respond and anticipate Russia's further 
manoeuvres in Crimea. Burke-White (2014) stated that Russia had smartly used this policy to defend its steps in engaging Crimea into its Federation from a legal perspective. Lastly, this policy had successfully increased domestic supports for and pride to the Russian Government, particularly from populist groups.

\section{NOTES}

i The "near abroad" refers to the newly independent republics which emerged from the dissolution of the Soviet Union.

\section{REFERENCES}

Aggarwal, V.K. (1998). Institutional designs for a complex world: Bargaining, linkages, and nesting. New York: Cornell University Press.

Alisson, R. (2014), Russian 'deniable' intervention in Ukraine: How and why Russia broke the rules. International Affairs, 90, 6, 1255-1297

Balasevicius, T. (2017), Looking for little green men: Understanding Russia's employment of hybrid warfare. Canadian Military Journal, 17, 3, 17-28.

Barber, N. (2017), A warning from the Crimea: Hybrid warfare and the challenge for the ADF. Australia Defence Journal, 201, April, 46-58. Retrieved from http://www.defence.gov.au/adc/adfj/Documents/issue_201/Barber_April_2017.pd $\mathrm{f}$

BBC. "Alexei Navalny: Russia's vociferous Putin critic" (2018, March 15), BBC. Retrieved from https://www.bbc.com/news/world-europe-16057045

Burke-White, W. W. (2014), Crimea and the international legal order. Journal Survival Global Politics and Strategy, 56, 4, 65-80

Cadier, D. \& Light, M. (2015). Russia's foreign policy: Ideas, domestic politics and external relations. New York: Palgrave Macmillan.

Chandler, A. "Defying U.S, Russia takes control of Crimea" (2014, March 1), The Atlantic. Retrieved from https://www.theatlantic.com/international/archive/2014/03/defying-us-putin-asksrussian-parliament-authorize-troops-ukraine/358698/

Cornel, M.E. \& Evans, R. (2016), Russia's ambiguous warfare and implications for the U.S. marine corps. Marine Crops University Journal, 7, 1 Spring, 30-45

Delcour, L. \& Wolczuk, K. (2015), Spoiler or facilitator of democratization? Russia's role in Georgia and Ukraine. Journal Democratization, 22, 3, 459-478.

Dugas, M. E. (2016), Between Georgia and Crimea: The social dimensions of war for the Russian military (Honor Thesis), Massachusetts: Wellesley College. Retrieved from Wellesley College Digital Scholarship and Archive.

Geleotti, M. (2015). Hybird war" and "little green men": How it works and how it Doesn't. In A. Pikulicka-Wilczewska \& R. Sakwa (Eds.), Ukraine and Russia: People, politics, propaganda and perspectives (156-164). Bristol: E-International Relations Publishing.

"Footprints of the Russian military intelligence agency GRU are everywhere" (2018, July 20), Raam Op Rusland. Retrieved from https://www.raamoprusland.nl/dossiers/militair-beleid/1028-footprints-of-therussian-military-intelligence-agency-gru-are-everywhere 
Gillich, I. (2015), Illegally evading attribution? Russia's use of unmarked troops in Crimea and international humanitarian law. Vanderbilt Journal of Transnational Law, 48, 1191-1223.

Goldsmith, B. E. (2005). Imitation in international relations: Observational learning, analogues and foreign policies in Russia and Ukraine. New York: Palgrave Macmillan.

Hedenskog, J. (2018). "Crimea After the Georgian Crisis” (2008, November), FOI

Swedish Defence Research Agency. Retrieved From https://www.foi.se/restapi/report/FOI-R--2587--SE

Iasiello, E. J. (2017), Russia's improved information operations: From Georgia to Crimea. Parameters, 47, 2, 51-63.

Kofman, M., et.al. (2017). Lessons from Russia's operations in Crimea and Eastern Ukraine. Santa Monica: RAND Corporation.

Kuzio, T. (2016), Nationalism and authoritarianism in Russia: Introduction to the special issue. Journal Communist and Post Communist Studies, 49, 1, 1-11.

Lentner, H. H. (1974). Foreign policy analysis: A comparative and conceptual approach. New York: Bell \& Howell Company.

Levy, J. S. (1994), Learning and foreign policy: Sweeping a conceptual minefield. International Organization, 48, 2, 279-312

Lowe, C. "Georgia war shows Russian army strong but flawed" (2008, August 21), Reuters. Retrieved from https://uk.reuters.com/article/us-georgia-ossetia-militaryidUKLK23804020080821

Mazitans, K. (2014), Russian armed forces military reforms and capability development (2008-2012). Baltic Security and Defence Review, 16, 1, 5-45.

Miller, C. "What Putin really feared in Ukraine" (2014, September 17), Foreign Policy Research Institute. Retrieved From https:/www.fpri.org/article/2014/09/whatputin-really-feared-in-ukraine/

NATO. "NATO-Ukraine Commission stresses continued engagement" (2014, February 27), NATO. Retrieved from https://www.nato.int/cps/su/natohq/news_107520.htm

Nygren, B. (2008). The rebuilding of greater Russia: Putin's foreign policy towards CIS Countries. New York: Routledge.

Pandey, S. K. (2010). Reassessing Russian Foreign Policy: Eurasianism and pragmatism combined. In K. Santhanam (Ed.), Eurasia security matters (55-70). New Delhi: Allied Publishers.

Reuters. "Russia lost 64 troops in Georgia war, 283 wounded” (2009, February 21), Reuters. Retrieved from https://uk.reuters.com/article/us-russia-georgiadeaths/russia-lost-64-troops-in-georgia-war-283-woundedidUKTRE51K1B820090221

Rotaru, V. (2018), Instrumentalizing the recent past? The new cold war narrative in Russian public space after 2014. Post Soviet Affairs, 35, 1, 25-40

Sofer, K. "Concrete steps to address the crisis in Ukraine" (2014, March 12), Centre for American Progress Report. Retrieved From https://www.americanprogress.org/issues/security/reports/2014/03/12/85775/concretesteps-to-address-the-crisis-in-ukraine/

Synder, R. C., Bruck, H. W. \& Sapin, B. (2002). Foreign policy decision making. New York: Palgrave Macmillan.

Talmon, S. (2009), The recognition of the Chinese government and the convention on international civil aviation. Chinese Journal of International Law, 8, 1, 135-159. 
Thomas, T. (2015), Russia's military strategy and Ukraine: Indirect, asymmetric - and Putin. The Journal of Slavic Military Studies, 28, 3, 445-461.

Welt, C. "Russia: Background and U.S. Policy" (2017, August 21), Congressional Research Service Report. Retrieved from https://fas.org/sgp/crs/row/R44775.pdf

Ziegler, C. E. (1993). Foreign policy and east asia: Learning and adaptation in the Gorbachev era. New York: Cambridge University Press. 